\title{
WILL-MAKING (WASIYYAH) IN ISLAM: A JURISTIC EXPOSITION
}

\author{
Taiwo Moshood Salisu ${ }^{1}$
}

\begin{abstract}
Islam is not averse to the acquisition of wealth and property, as it recognizes various legitimate means through which property can be amassed, such as zakāh (alms due), șadaqah (charity), hibah (gift), miräth (inheritance), and wașiyyah (bequest). It not only places importance on the even distribution wealth but also urges man to see wealth and property as Allah's trust (amānah). Therefore, He (Allah) directs man on how wealth and property should be evenly distributed. However, a commonality between the concepts of wasiyyah and mìnth is death. In other words, neither of the two could be viewed or discussed without the latter. However, Muslims the world over, especially the nominal ones, do not want to entertain this reality. This raises questions such as: What is the disposition of Muslims to the concept of willmaking? Are Muslims acquainted with the act of writing bequest? Does child favoritism have implications on will-making? Of what essence is bequest in Islam? What differentiates bequest in Islam from other forms of will-making? This paper reacts to the above questions. Thus, the onus of this paper is present an expository account on the concept of wasiyyah with a view
\end{abstract}

1 Senior Lecturer, Department of Religions and Peace Studies, Lagos State University, Lagos State, Nigeria, tmsalisu1965@gmail.com; salisutm1965@ yahoo.com 
towards ascertaining its place in the practice of Islam on the one hand and demystify the fear that is often associated with it by the adherents of Islam on the other. The method adopted is a descriptive survey while our findings revealed that Allah's Ordinance is supreme and divine, hence, Muslims should neither be apologetic on Allah's instruction concerning will-making nor fail to comply with its underlying instruction.

Keywords: wașiyyah, Islam, juristic, exposition

\section{INTRODUCTION}

Wealth and property, according to Imām al-Ghazālī and al-Shātịīi, are one of the necessities that constitute de facto in the conservation and management of social life. The other necessities according to them include: religion ( $d \bar{i} n)$, life (hayyāt), soul (nafs) intellect ('aql) and lineage/progeny (nasab/nasl). ${ }^{2}$ The desire for the acquisition of property is as old as Islam, for it is natural for man to yearn for wealth if only for his survival on one hand and for his comfort on the other hand. However, Islam seeks to regulate that impulse. For example, it is natural for man to satisfy this natural urge while Islam plays a benchmark role towards satisfying it. In fact, Islam does not only see wealth and properties as belonging to Allah but that they are trust (amānah) and man is a trustee. It is, according to Adetona, "a source of test for man like other ephemeral gifts"3 Ibn Ahmed Olgar succinctly writes in this regard:

"If we fully understand that wealth is a trust (amānah) given to us by Allah SWT and Allah is testing us to see how we will discharge the wealth, this would be the stepping stone to us using our wealth in accordance with the commandments of Allah SWT and thereby gaining the everlasting pleasure of Allah and attaining felicity (al-Jannah)." 4

Therefore, the right to own property should be exercised within the confines set by Allah. In other words, man's right to property is not personal,

2 Fazlur-Raḥmān, 'Economic Principles of Islam,' in Studies in Islamics Economics, ed. Khurshid Ahmad (United Kingdom: The Islamic Foundation, 1980/1400AH), 2 .

3 L. M. Adetona, 'Aspects of Islamic Law: Acquisition and Distribution of Wealth and Penal Code,' in Diploma in Arabic and Islamic Studies Students' Handbook, ed. M. A. Muhibbu-Dīn \& A. I. Lawal (Lagos: Arabic and Islamic Studies Units of the Lagos State University, 1998), 195.

4 Moulana Moosa Ibn Ahmed Olgar, The Book of Wealth (South Africa: Tarbiyat Publications, 2001), 5. 
but limited and qualified, says Raheemson. ${ }^{5}$ Islamic Law catalogs several ways through which man can acquire wealth and property. These include: wages for services, self-esteemed labour, expertise and/or other lawful occupation and engagements, inheritance or succession (mīrāth), bridal gift (sadāq), alms tax (zakāh), gift (hibah), trading/exchange of goods and services (tijārah/bay 'ah), endowment (waqf), voluntary charity (șadaqah) and bequest (wașiyyah).

Although these are legitimate means through which wealth and property could be amassed in Islam, this research is only intended to elucidate a juristic exposition on wasiyyah (bequests/legacies) with the purpose of making it a mainstream concept in Islam.

\section{CONCEPTUAL MEANING OF AL-WAȘIYYAH IN ISLAM}

Al-Wașiyyah, linguistically hails from the word wașa which means 'to command' or 'to instruct" or 'to obligate' or 'to convey'. ${ }^{6}$ According to Cowan, it could mean 'legacy' and 'testamentary disposition'. ${ }^{7}$ The literal meaning suggests, "imposition upon someone or command with something," but technically, "a special pledge to donate something after death". ${ }^{9}$ According to Imām Muhammad Idrīs al-Shāfi' ${ }^{1} \overline{1}$, wașiyyah means "authorizing possession of one's wealth or possessions to someone else after one's death by way of

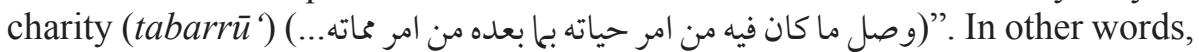
it is a set of instructions given by a person to individuals whom he expects to survive him. ${ }^{10}$ To the lexicologists, it connotes making the word of advice a

5 M. O. Raheemson, 'Ethics of Trade Transaction in Islam and its Relevance in Contemporary Times,' (Ph.D Thesis, Department of Arabic and Islamic Studies, University of Ibadan, 2001), 5-10.

$6 \quad$ Edward William Lane, Arabic-English Lexicon, Book 1-Part 8 (London: William and Norgate, 1893), 2944.

7 J. Milton Cowan (ed.), A Dictionary of Modern Written Arabic (London: Macdonald \& Evans Ltd., 1974), 1075.

8 Ibn Manz̦ūr al-Ifriqīi, Lisān al- 'Arab, vol. 6 (Cairo: Dār al-Ma'rif, n.d.), 4853.

9 Muḥammad b. 'Alī b. Muḥammad al-Shawkani, Nayl Awțār, Sharh Muntaqī alAkhbār min Ahạdīth Sayyid al-Akhyār, vol. 5 (Beirūt, Lebanon: Dār al-Fikr, 2010), 142.

10 Imām Muhammad Ibn Idrīs al-Shāfi‘̄i, al-Umm, vol. 5 (Cairo: Dār al-Ḥadīth, 1439AH/2008), 5; Abdulmumini A. Oba, 'Can A Person Subject to Islamic Law Make A Will in Nigeria?: Ajibaiye vs Ajibaye and Mr. Dadem's Will Goose Chase,' in CALS: Review of Nigeria Law and Practice, vol. 2/2 (2008): 140 
modus operandi (rule of procedure) and in Shariah, it is a testament which is to be acted upon after the death of the person who made it. ${ }^{11}$

Therefore, wasiyyah could summarily be seen as an outstanding directive pre-arranged by a person in respect of certain outstanding duties against him, which he/she overtly or covertly did not carry out before his/her death. It may be an order that a debt he owed be paid to his creditor or the zakāh outstanding against his wealth be deducted from his estate or hajj promised before his/her death be performed. It may also be that a property entrusted to him be handed over to the rightful owner(s) or a portion of the property he left behind be utilized for charitable deeds in favour of an individual or organization.

\section{BASIS OF WILL-MAKING IN ISLAM: QUR'ANIC AND $A H \bar{A} \bar{A} \bar{I} T H$}

The word wasiyyah, overtly or covertly, appears in nine places in the Quran and in each case it connotes legacies/bequests. Similarly, the word appears in different forms in several other places. These include words like wașșa, wașṣākum (command), wașaynā (directive), wa'awșānī (enjoin), yūṣīkum, $y \bar{u} s ̦ \bar{l}$ and $y \bar{u} s ̦ \bar{a}$ (directive), tawșiyatan (dispose) etc. The table below shows the different usages of the word in the Quran.

Table 1: Different Usages of the Word in the Quran.

\begin{tabular}{|c|c|c|c|}
\hline No. & Qur'anic Usage & Connotation & Surah \& Verse \\
\hline 1. & wașṣā & Legacies & $\begin{array}{l}\text { Surah al-Baqarah, 132; } \\
\text { Surah al-Shūra, } 13\end{array}$ \\
\hline 2. & wașșākum & Command & $\begin{array}{l}\text { Surah al-An'ām, 151, } \\
152 \& 153\end{array}$ \\
\hline 3. & wașșaynā & Directive & Surah al-Nisā', 131 \\
\hline 4. & wawașșaynā & Directive & $\begin{array}{l}\text { Surah al-'Ankabūt, 8; } \\
\text { Surah Luqmān, 14; } \\
\text { Surah al-Shūra, 13; } \\
\text { Surah al-Aḥqāf, 15 }\end{array}$ \\
\hline 5. & wa'awșānn̄ & Enjoined on me & Surah Maryam, 31 \\
\hline 6. & $\begin{array}{l}y \bar{u} s \grave{i} k u m ; \quad y \bar{u} s \underline{\bar{l}} ; \text { and } \\
y \bar{u} s \underline{a} \bar{c}\end{array}$ & $\begin{array}{l}\text { Directive/ } \\
\text { command }\end{array}$ & Surah al-Nisā', 10 \& 11 \\
\hline
\end{tabular}

11 Al-Hafīz Ibn Hajar al-'Asqalān̄̄, Bulūgh al-Marām: Attainment of the Objective According to Evidence of the Ordinance (Riyāḍ: Dār al-Salām Publications, 1996), 339. 


\begin{tabular}{|c|c|c|c|}
\hline No. & Qur'anic Usage & Connotation & Surah \& Verse \\
\hline 7. & wașiyyah & Legacies/bequests & $\begin{array}{l}\text { Surah al-Baqarah, 180; } \\
\text { 240; } \\
\text { Surah al-Nisā', 11; } \\
\text { Surah al-Mā'idah, } 106\end{array}$ \\
\hline 8. & tawșiyatan & Bequest/Will & Surah Yāsīn, 50 \\
\hline 9. & tūṣūnna & Bequeathed & Surah al-Nisā', 12 \\
\hline 10. & $y \bar{u} \sin \bar{a}$ & Bequeathed & Surah al-Nisā', 12 \\
\hline
\end{tabular}

Source: Muḥammad Fuwād 'Abd al-Bāqī, al-Mu 'jam al-Mufahris li Alfāza alQur'ān al-Karīm (Beirūt: Dār al-Fikr, 1987).

It is used to connote a direct/indirect as when Almighty Allah says:

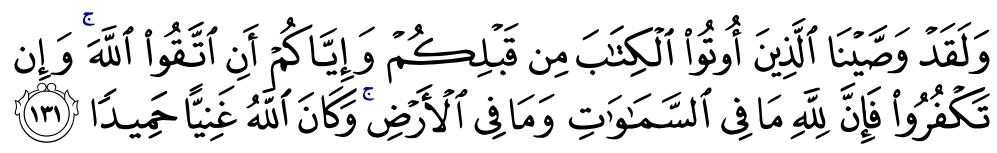

"Verily, we have directed the people of the Book before you, and you (O Muslims) to fear Allah. But if you deny Him, lo! Unto Allah belong all things in the heavens and on earth, and Allah is free of all wants, worthy of all praise."

(Surah al-Nisā', 4: 131)

The same word 'wașaynā' is used three times in enjoining man to be kind and dutiful to his parents. Allah says: “.... ووصّينا الإنسان بو الديه حسنا " i.e. "We have enjoined on man (to be good) to parents..." ${ }^{12}$ The following legal injunctions lend credence to the technical usage of the word in the Holy al-Quran:

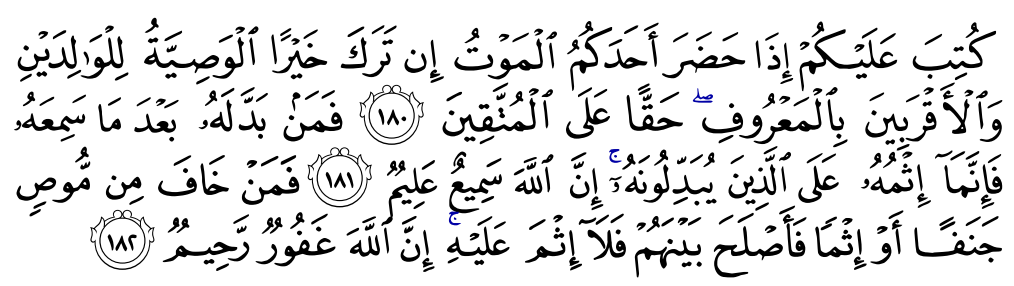

12 Qur'an 29: 8; 31:14 \& 46:15. The divine call for kindness to parents in the latter verse is premised on the fact that parents were instrumental to the existence of man in life most especially the mother who bore his pregnancy. 
"It is prescribed for you when death approaches any of you, if he leaves abundant wealth that he make a bequest to parents and the next of kin according to the reasonable usage; This is due to from God-fearing. If anyone changes the bequest after hearing it, the guilt shall be on those who make the change. For Allah hears and knows (All things). But, if anyone fears partiality or wrong doing on the part of the testator and makes peace between (the parties concerned), there is no wrong in him: For Allah is oft-forgiving, Most merciful."

(Surah al-Baqarah, 2: 180-182)

Abdur-Rahmān Doi notes that the above Quranic verses were revealed when there was no law guiding bequest or inheritance. ${ }^{13}$ 'Abd Allāh Yūsuf 'Alī opines that it is ideal for a dying person to be favorably disposed to his parents and next of kin, especially 'in a spirit of love and reverence' for those who have cherished him/her and 'not in a spirit of injustice' to any other person, albeit in accordance with a reasonable manner ${ }^{14}$ It has also been posited that the above verses, especially verse 180 and 240, of the same sürah are good instances of the concept of abrogating and abrogated verses in the al-Quran (nassikh wa mansūkh) at least according to Imām Shāfi' $\overline{1}$. Doi writes in this regard:

"Imām Muhammad Idrīs al-Shāfi'ì has discussed the following two verses of the Holy Qur'an showing an example of abrogating (nāsikh) and abrogated (mansükh) verses and the role of sunnah and ijmá 'in deciding the rule of law on wasiyyah." 15

Al-Ṭabarī (d.310/923) strongly surmises that the two verses may be conceived as either a confirmation of bequests for parents, near relatives and for the wife, or inheritance together with bequests with a view to making the two lawful or that the legislation concerning the former abrogates the latter. ${ }^{16}$ Similarly, Muhammad Taqī al-Dīn al-Hilālī and Muḥammad Muḥsin Khān share the same opinion with Imām Shāfi‘ $\overline{1}$; that the latter might influence the views of the former. ${ }^{17}$ Those who claim the verse of succession as being

13 Abdur-Raḥman Doi, Sharī 'ah: The Islamic Law (London: Ta-Ha Publishers Ltd., 1984), 328.

14 'Abdullah Yūsuf 'Al̄̄, The Qur'ān: Translation and Commentary (England, IPCI: Islamic Vision, 1999), 75.

15 Abdur-Rahmān Doi, Sharī'ah: The Islamic Law, 331.

16 Muḥammad b. Jarīr al-Țabarī; Jāmi ‘ al-Bayān 'an Tā'wīl al-Qur'ān, vol. iii, ed. Shākir (Misr: Dār al-Ma'arif, n.d.), 30.

17 Muḥammad Taq̄ī al-Dīn al-Hilālī \& Muhammad Muḥsin Khān, The Noble Qur'an: English Translation of the Meanings and Commentary (Madina: King Fahd Complex for the Printing of the Qur'àn, 1404A.H.), $36 \& 53$. 
abrogated (mansūkhah) according to Tafsīr Ibn Kathīr include: Ibn 'Umar, Abū Mūsā, Ibn Musaiyyib, al-Ḥasan, Mujāhid, 'Ațā’a, Ibn Sirīn, Qatādah, alNakhā'i, Shurayḥ, al-Dhaḥḥāk, al-Zuhrī and others. ${ }^{18}$

Abū al-A 'lā Mawdūdī sheds light on the Quranic verse of bequests in the following words:

"This Commandment about making a will was given at the time when the law of inheritance had not as yet been prescribed. Its object was to safeguard the lawful heirs against injustice. But afterwards, this commandment was modified by the Holy Prophet in the light of the law of inheritance laid down in the Qur'ān in Chapter IV. First, no one could bequeath anything to a legal heir, that is, no decrease or increase could be made in the shares fixed by the law and no heir could be deprived of his shares nor could he get anything more than his legal shares. Second, bequest was limited to one-third of the property only. That is, one should leave at least two-thirds of one's property to the heirs to be divided among them according to the Law, but may leave by will only onethird of his property to those of his indigent relatives who might not have been entitled by law to any share in the inheritance, or for public works, etc. It is, therefore, wrong to say that the law about making a will has been abrogated. On the other hand, it is a right imposed by Allah on the God-fearing people and if this right is exercised properly, many problems, such as the inheritance to an orphan, grandson etc. will be solved without tampering with the Islamic code of inheritance." 19

However, one may be compelled to submit to the emphatic statement of the Prophet PBUH:

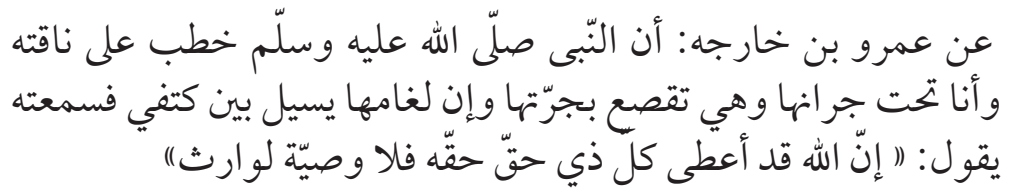

"Narrated 'Amru bin Khârijah (PBUH) that the Prophet SAW addressed people on his camel while I was under its neck and she toss down her neck while mouth's foam is flowing between my two

18 Ibn Kathīr, Tafsīr al-Qur'ān al- 'Ażìm, vol. 1 (Beirūt: Dār al-Andalus, 1966), 372.

19 S. Abū al-A'lā Mawdūdī, The Meaning of the Qur'ān: Arabic Text with Translation and Commentary, vol. 1 (London: n.p., n.d.), 136. 
shoulders and I heard him (PBUH) saying: "Allah has appointed for everyone who has a right what is due to him and no bequest must be made to an heir." 20

The Quranic legislation on mìrāth ${ }^{21}$ has abrogated the verse on wașiyyah for parents and wives since they are now Quranic heirs, although bequests for relatives still subsists. Abdul Malik Bappa Mahmud gives an interpretation of this stance when he writes:

"If a testator gave or indicated in his testament that part of his property be given to a woman and then before his death, he married the woman, then her right to claim part of the property as directed in the testament was no more valid." 22

In the same token, Doi corroborates:

"Bequests to parents are no longer valid, since their right to inheritance as successor is confirmed. A bequest made by a deceased to anyone who is not a successor is valid. It is commendable if the deceased leaves a bequest to his relatives." ${ }^{23}$

It is also important to note that the Glorious Quran unequivocally made it lucid in al-Quran 4:12 that the Quranic heirs are to take their shares after the necessary deductions such as: liabilities, payment of alms due (zakāh), funeral expenses (janāzah), debts (duyūn) and other legacies (wașayyah) that they may have been bequeathed etc. Al-Quran says in this regard:

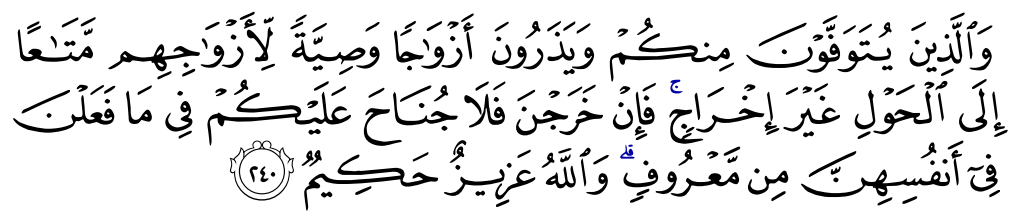

"And those of you who die and leave behind wives should bequeath for their wives a year's maintenance and residence without turning them out, but if they (wives) leave, there is no sin on you for that which they do of themselves, provided it is

20 Imām Muḥammad bin 'Alī bin Muhammad al-Shawkānī, Nayl al-Awțār: Sharh Muntaqū al-Akbar min Ahādīth Sayyid al-Akhyār, vol. 5 (Beirūt: Dār al-Fikr, 2010), part 6, no. ḥadīth 2516-2517; al-Ḥāfiz Ibn Ḥajar al-'Asqalānī, Bulūgh al-Marām, 339.

21 al-Quran 4: 11-12 \& al-Quran 2: 240.

22 Abdul Malik Bappa Mahmud, Supremacy of Islamic Law (Zaria: Hudahuda Publishing Company, n.d.), 53.

23 Abdur-Raḥmān I. Doi, Sharī'ah: The Islamic Law, 332. 
honourable (e.g. lawful marriage). And Allah is All-Mighty, AllWise."

$$
\text { (Surah al-Baqarah, 2: 240) }{ }^{24}
$$

Initially, prior to the revelation of the Quran 2: 240, wașiyyah was necessary for widows and entailed lodgings and maintenance for a year. Similar to the above tradition of the Arabs is the custom of sharing properties with one's brothers and friends, which was in vogue before the advent of Islam. Therefore, contrary to this custom the Quran states:

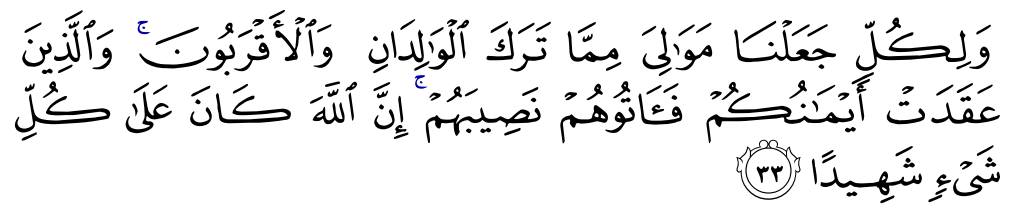

"And to everyone, we have appointed heirs of that (property) left by parents and relatives. To those also with whom you have made a pledge (brotherhood), give them their due portion (by wașiyyah) wills. Truly Allah is Ever a Witness over all things."

(Surah al-Nisā', 4: 33)

Mawdūdī regarded this act as "act of Jähiliyyah" when he states:

"Verse 33 abolished an old custom of the Arabs. They enter into agreements of friendship and brotherhood with each other and on the score of these were entitled to the inheritance of each other. Likewise a god-son became heir of his god-father. Here this custom of "ignorance" has been abolished, and it has been enjoined that the inheritance should be divided among the heirs according to the law prescribed by Allah. They are, however, allowed to give to such people, during their lifetime, what they like." 25

According to the Shariah, one is entitled to make a will or bequest for onethird of their property and not beyond that, so that, the rights of the legal heirs are not jeopardized or compromised.

The genesis of will-making occured according to a tradition reported by Ibn 'Umar:

24 Muhammad Taq̄i al-Dīn al-Hilālī and Muhammad Muhsin Khān notes that this verse has been abrogated by the earlier quoted verse (Qur'ān 4: 12); See Muhạmmad Taqī al-Dīn al-Hilālī and Muhammad Muhsin Khān, The Noble Qur'an: English Translation of the Meanings and Commentary, 53.

25 S. Abū al-A'la Mawdūdī, The Meaning of the Qur'ān, 324-325. 


$$
\begin{aligned}
& \text { عن عبد الله بن عمر رضي الله عنهـا أنّ الرّسول صلى الله عليه وسلم }
\end{aligned}
$$

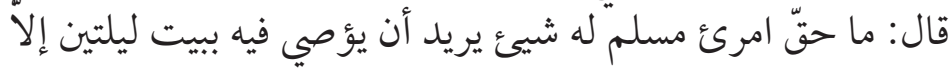

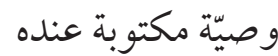

" 'Abd Allah Ibn 'Umar reported the Messenger of Allah, PBUH said: "It is not right for a Muslim who has property regarding which he must make a will that he should sleep for two nights save that his will should be written down with him.." 26

However, it should be noted that "yubitu laylatayn" mentioned in the above tradition technically connotes "swiftness". ${ }^{27}$ Perhaps the "swiftness" referred to here informs Ajetunmobi's stance when he elucidates:

"Jurists are unanimous in their interpretation of the time mentioned in the hadith, that the mentioned number of days are meant to urge Muslims to make urgent their wills because they may not know the suddenness with which death may overtake them." 28

In another tradition, Sa'ad Ibn Abī Waqqās relates:

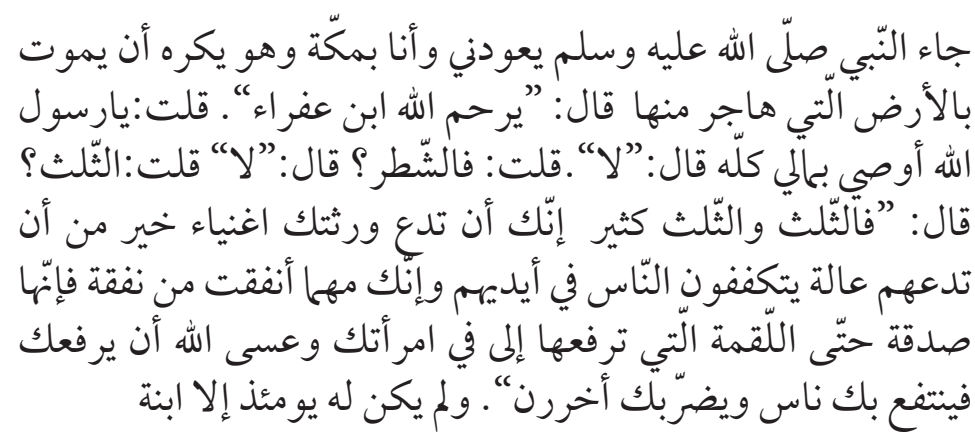

"The Prophet PBUH came visiting me while I was (sick) in Makkah and he loathed to die in the land, hence he had already

26 Muhammad bin Ismā‘̄il al-Amīr al-Yaman̄̄ al-San'an̄i; Subl al-Salām: Sharḥ Bulūgh al-Marām min Jāmi ' Adillat al-Ahkām, vol. 3 (Cairo: Dār al-Fajr li alTurāth, 2005), 141; al-Ḥāfiz Ibn Hajar al-Asqalān̄̄, Bulūgh al-Marām min Adillat al-Ahkā̄m (Riyāụ: Maktabah Dār al-Salām, 1993), 285, chapter 21, Bāb al-Wașāyā, no. hạadìth 951.

27 A. R. Jazā'irī, Kitāb al-Fiqh 'alā al-Madhāhib al-Arba'ah, vol. 3 (Cairo: alMaktabah al-Tijāriyyah al-Kubrah, n.d.), 315.

28 M. A. Ajetunmobi, 'Modern Development in Islamic Law of Testamentary Disposition,' Hamdard Islamicus: A Quarterly Journal of Bayt al-Hikmah, vol. xv (1992): 77. 
migrated. He (the Prophet) said: may Allah bestow His Mercy on ibn 'Afrä' (Sa'd bn. Khawla). I said, $O$ the Messenger of Allah! (peace and blessing of Allah be on him), May I will all my property (in charity)?" He said, "No" I said, "Then may I will half of it"? He said, "No" I said, "One third?" He said: "Yes, one third, yet even one third is too much. It is better for you to leave your progenies rich than to leave them poor begging others, and whatever you spent for Allah's sake would be considered as a charitable deed even the handful of food you put in your wife's mouth. Allah may lengthen your age so that some may benefit by you, and some others be harmed by you." At that time, Sa 'd had only one daughter." 29

Al-Jazā'irī posited that two things are beyond man's control, one of which is the two-thirds of his property (mīrath) and the prayers of Allah's servants for him after the expiration of his life. However, man has control over the onethird (i.e wasizyah), for this purifies and sanctifies his wealth and property. ${ }^{30}$ It is not out of place, therefore, to conclude that giving out one's property as 'will' is akin to sadaqah, since the latter purifies and sanctifies Muslim's properties just like zakāh. In the same vein, will-making could be likened to a 'gift' (hibah), for their modus operandi according to Ajetunmobi is identical, albeit with a slight difference. The difference lies in the fact that the benefactor/ recipient (mūssa lahu) of the former begins to enjoy it after the demise of the testator $(m \bar{u} s \bar{l})$ while the benefactor of the latter enjoys it when the donor is still alive ${ }^{31}$ It is also noteworthy that Shariah permits giving out one's property as a 'will' in proxy just as performance of hajj in proxy is valid. A tradition of the Prophet attests:

29 Sayyid Sābiq, Fiqh Sunnah, vol. 3 (Lebanon: Dār al-Fikr, 1983), 447. See Muhammad Mahdi al-Sharif (trans.), Sunan An-Nasā' 'i: The Fifth Correct Tradition of the Prophetic Sunna, vol. 3 (Beirūt, Lebanon: Dār al-Kutub al'Ilmiyyah, 2008), 197, no. ḥadīth 3627. See: Muhammad bin Ismā'īl al-Amīr alYamanī al-San'an̄̄, Subl al-Salām: Sharh Bulūgh al-Marām min Jāmi ' Adillat alAḥkām, 144; al-Hāfiẓ Ibn Ḥajar al-'Asqalānī, Bulūgh al-Marām, 339; Muḥammad 'Alī, A Manual of Hadìth (Lahore: The Ahmadiyyah Anjuman Ishaat Islam, n.d.), 333.

30 Abū Bakar Jābir al-Jazā'irī, Minhāj al-Muslim, $8^{\text {th }}$ ed. (Lebanon: Dār al-Fikr, 1976), 363.

31 M. A. Ajetunmobi, 'Modern Development in Islamic Law of Testamentary Disposition,' 76. 


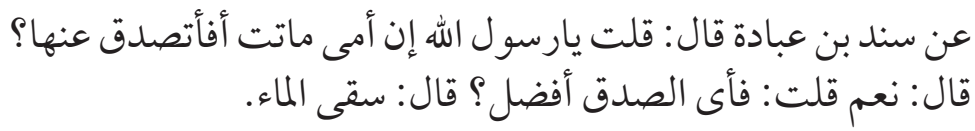

"Narrated Sanad bin 'Abādah: He said to the Prophet PBUH, "O! Allah's Messenger my mother had died, should I give sadaqah on her behalf?" He replied, "Yes" He said again: "Which of the sadaqah is the best?" He (Rasūl Allah) replied: "Provision of water." 32

Having viewed the concept of wasiyyah from the view of the Quran and ahāaith, what is the juristic disposition to it? The concern of the next section.

\section{JURISTIC BASIS OF WAṢIYYAH IN ISLAM}

Wasiyyah is fundamental in Islam, for it constitutes one of the commandments of Allah (awāmir Allah) ${ }^{33}$ and it is gauged with the fiqh benchmark which determines the imperativeness of other similar commandments such as salät, șawm, hajj, nikāh, recording of transactions, seeking forgiveness, abandonment of sins, etc. In other words, these benchmarks are applicable to other forms

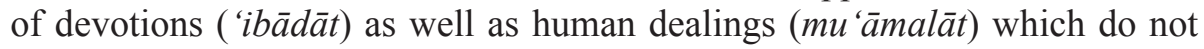
only have a religious motif and endorsement, but are also binding on Muslims. The benchmarks, jurisprudentially, are classified into five; obligatory (wäjibah), recommended (mandūbah), permissible (mubāhah), reprehensible (makrūhah), and possibly prohibited (muharramah).

In other words, wasiyyah, is said to be obligatory (al-wasiyyah alwajibah) on every conscious Muslim who has property to leave behind or an unaccomplished task before their death. It is also a testamentary document which features the rights and possessions of others ( huqūq al-insān), like items for safekeeping belonging to someone else or debts that must be settled. It would be desirable/recommendable (al-wașiyyah al-mustahabah/mandübah) when a person intends to give charity or that which basically settles the rights of Allah (huqūq Allah) like outstanding alms-giving (zakāh) and penalty incurred during Ramadān (fidyah al-șiyām). A permissible will (al-wașiyyah $a l-m u b \bar{a} h a h)$ is that of the rich for his/her relatives and kin that were not within

32 It should be noted that this hadīth has other versions such as the șighah narrated by 'Ā'ishah RA, Ibn 'Abbās RA etc. See: Imām Ibn Hajar al-'Asqalānī; Fath al-Bārī: Sharh Șaḥ̄h al-Bukhārī, vol. 5 (n.p.: Dār al-Bayān al-'Arabī, n.d.), 448.

33 For a detailed discourse on the concept of Amr in Islamic Law, see A. O. Omotosho, 'The Language Factor in the Interpretation of Islamic Law: The Word Amr in Focus,' Nasarawa State University Law Journal, vol. 1/1 (2004): 131-142. 
the confines of the Quranic specifications. On the other hand, a reprehensible (al-wașiyyah al-makrūhah) is when the wealth is insufficient while tawșiyah becomes prohibited/forbidden (al-wasiyyah al-muharramah) when the aim of making it is to harm or displace the heir apparent(s) or is capable of causing harm to any of the heirs wittingly or unwittingly. In the same vein, it would also be forbidden if the document exhorts or instructs on commitment of vices and sinful acts, such as embalmment after ones death, instruction on the use of alcoholic wines and drinks during ones funeral, and cremation of one's body after death except on medical advice; perhaps as a result of epidemics or spread of certain contagious viruses such as Ebola and the likes, etc.

Shafi'ites agree with the Hanafites definitions of obligatory and forbidden wills. They also have the concept of 'reprehensible wills' as that which exceeds one-third, while they define a 'permissible will' as one for the relatives who are not heirs of the deceased or for the poor. Malikis also approves the same save the fact that they give other names to it. Hanbalis proposed four kinds of wașāya vis-à-vis: Wașiyyah al-wäjibah is like that described by other jurists save that they include the rights of Allah (huqūq Allāh) like outstanding zakāh and performance of hajj; Wașiyyah al-mustahabah is for one's poor relatives who are not heirs of the deceased on proviso that the testator left sufficient property or legacy according to the understanding of the tradition or custom of the land ('urf) and that it does not exceed one-fifth of the deceased property so that the rights of the heirs are not compromised; a detestable will is that of a testator who is not only well-off but also causes problems for his needy heirs; and finally the prohibited will is that which is more than one-third. Thus, they forbid anyone who has heirs from doing this ${ }^{34}$ Muhammad b. Isma'il al-Sanani likened the status of wașiyyah with that of nikäh which can be compulsory, required, permissible, detested and prohibited. ${ }^{35}$ The significance of wașiyyah according to Sayyid Sābiq ${ }^{36}$ is underpinned by the hadìth that states:

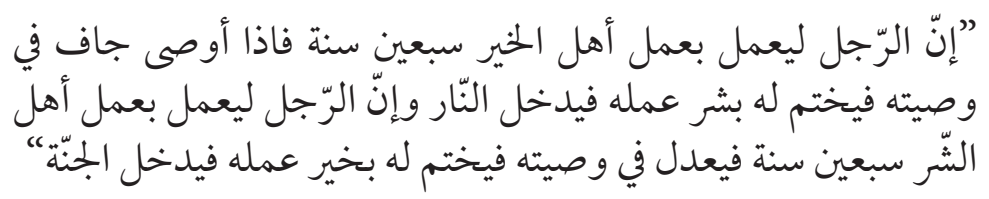

34 M. J. al-Mughniyyah, al-Fiqh 'alā Madhāhib al-Khamsah, vol. 2, $6^{\text {th }}$ ed. (Beirūt: Dār al-'Ilm li al-Malayin, 1979), 134.

35 Muḥammad b. Ismā‘̄̄l al-San'an̄̄, Sublu al-Salām, vol. iii (Beirūt: Dār al-Fikr, n.d.), 103. See also T. M. Salisu, 'The Infiltration of Custom ( $a l-' \bar{A} d a h)$ into Islamic Marriages in Yorubaland,' Journal of Religion and Culture, vol. 1/2 (2000): 60.

36 Sayyid Sābiq, Fiqh al-Sunnah, vol. 4 (Cairo: Dār al-Fatih al-I'lam al-'Arabī, 1998). See also Abūbakar Sadiq Ogwuche, Compedium of Islamic Law (Lagos: Malyati Chambers, 2006), 83-87. 
"It is possible for a man to do good for seventy years and at the end he makes an unjust will which could make him end up in hell. In the same vein, it is possible for a man to do evil for seventy years and at the end be just in his will and that will be his last work and earns him Paradise." 37

The fuqahā', however, differ on the status of wașiyyah. Those who rule it as farḍ/wäjib (obligatory) include: Ṭalha, al-Zubayr, al-Zuhrī, , 'Abd Allāh bn Abī 'Awfā, Țalḥa bin Mutarraf, Abi Sulaymān, Abū Mijlāz, Dāwūd al-Zahirī, Abū 'Awānah, al-Isfarāyaynī, ibn Jarīr, Isḥāq and the Zāhiriyyah ${ }^{38}$ while 'Abd Allāh b. 'Umar, al-Sha'bī and Ibn Hazm were added by another source. ${ }^{39}$ The Shafi'ites also share this view as reported by al-Bayhaq $\overline{1}^{40}$ It is important to note that those jurists who decree that wasiyyah as obligatory do not only differ on its scope but also its application. In other words, most say it is of general application while Tāwus, Qatādah, Ibn Jabīr, bin Zayd and others state that it is compulsory for those relatives who do not inherit from the estate. Abu Thawr states that the imperativeness manifests itself in the verse of inheritance and it has been explained in ahādith to whom it is to be given. ${ }^{41}$ Ajetunmobi states this position lucidly:

"Some other jurists agreed that the making of bequest is compulsory but they limit the compulsion to only the parents and close relatives as beneficiaries. Qatādah, Ibn Jarīr al-Tabarī and al-Zuhri belong to this class of jurists" ${ }^{42}$

It is noteworthy that the divergence of opinions (ikhtiläf) among the fuqaha ${ }^{\prime}$ may not be disconnected from the Quranic basis on will-making as to whether it is abrogated (mansükhah) or not. Thus, those jurists who see it as farḍ/wājib state that the verse of will-making is general ( ' $\overline{\mathrm{m}} \mathrm{mm}$ ) in its meaning as conveyed by the wording of the text (nașs) and has special application to parents who cannot inherit such as those non-Muslim parents of a new convert to Islam, as

37 Sayyid Sābiq, Fiqh Sunnah, vol. 3 (Lebanon: Dār al-Fikr, 1983), 443. See also: M. A. al-Shawkāni, Nayl al-Awțār: Sharḥ Muntaqū al-Akhbār Min Ahāāìth Sayyid al-Akhyār, vol. 5, 138.

38 A. M. Ibn Hazm, al-Muhalla, vol. 9 (Cairo: Dār al-Thurath, n.d.), 312.

39 M. A. Ajetunmobi, 'Modern Development in Islamic Law of Testamentary Disposition', 77.

40 M. A. al-Shawkāni, Nayl al-Awtār: Sharḥ Muntaqū al-Akhbār min Ahāāìth Sayyid al-Akhyār, 135.

41 I. D. Ibn Kathīr; Tafsìr al-Qur'ān al- 'Az̄ìm, 372-373.

42 M. A. Ajetunmobi, 'Modern Development in Islamic Law of Testamentary Disposition,' 77. 
well as relatives who do not succeed to the estate of a deceased. 'Abd Allāh ibn 'Abbās, in one ruling attributed to him and Qatadah the claim that all those inheriting by way of ayat al-mirāth (verse of bequests) are excluded from wasiyyah and all other persons have the right to wasiyyah ${ }^{43}$ The above position is corroborated in another hadīth narrated by Abu Usamah where the Prophet SAW declared: "Allah had granted the right due to everyone so there is no wașiyyah for the Quranic heir (wārith)" ${ }^{44}$ Imām al-Shāfi‘ 1 and most Malikis strongly share the above view. ${ }^{45}$ Indeed, Malikis see wasiyyah as a right (haqq) due from one-third of the possessions of the legator ('âqid al-wașiyyah/mūș $\overline{\text { ) }}$ or a due to someone by agency (niyābah) of the $m \bar{u} s \underline{\bar{l}}$. Hanbalis agree with the Malikis while Shāfi'īs restrict it to the wașiyyah only. The Zāhiriyyah opines that wașiyyah is binding on every Muslim leaving wealth behind.

\section{WILL-MAKING AND ITS JURIDICAL AMOUNT (MIQD $\bar{A} R A L-M \bar{A} L)$ IN ISLAM}

There are several ahāithth on the amount of will-making in Islam, although the aforementioned hadith of Ibn 'Umar is silent on the exact amount. Ibn "Abbās stated that "if only the people would reduce their will from a third to a quarter, because the Prophet PBUH declared regarding: “... a third and a third

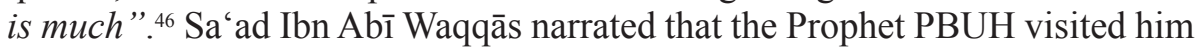
during his serious illness and he asked him (PBUH) if he could dispose of all his wealth as a will. The Prophet PBUH declined. The Prophet PBUH also rebuffed a half as a will, but concurred to a third, saying:

$$
\begin{aligned}
& \text { عن سعد بن أبي وقّاص رضي الله تعالى عنه قال: قلت: يارسول الله أنا }
\end{aligned}
$$

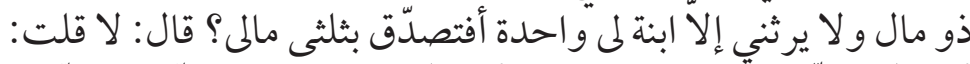

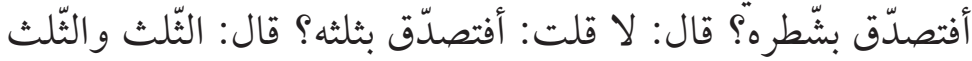

$$
\begin{aligned}
& \text { كثير إنّك إن تذر ورثتك أغنياء خير من أن تذرهم عالة يتكففون النّاس }
\end{aligned}
$$

"Narrated Sa'ad bin Abi Waqqas: I said, "O Allah's Messenger,

I have property and none heirs from me but only one daughter

$\overline{43}$ A. B. Ali-Sijistānī, Sunan $A b \bar{\imath} D \bar{a} w \bar{u} d$, vol. 2, $2^{\text {nd }}$ ed. (Cairo: Maṭba'ah Musṭafā al-Halabī, 1983), 113.

44 Muhammad b. Ismā‘̄̄l al-San'anī, Sublu al-Salām, 106.

45 A. A. al-Qurțūbī, al-Jāmi 'li Ahkē̄m al-Qur'ān, vol. 2, 3 ${ }^{\text {rd }}$ ed. (Cairo: al-Maktabah al-"Arabiyyah, 1967), 262-263.

46 M. D. Ibn Athar, Jāmi ‘ al-Ușūl fì Ahāàìth al-Rasūl, vol. 2, 1 1st ed. (Damascus: Maktabah al-Hilwān, 1970), 632. 
of mine. Shall I give two-thirds of my property as Șadaqah?" He replied, "No." I said, "shall I give half of it as Sadaqah?" He replied, "No." I said, "Shall I give a third of it as Sadaqah?" He replied, "You may give a third as Sadaqah, which is still a lot. To leave your heirs rich is better than to leave them poor and begging from people..." 47

Abū Dardā'i narrated that the Prophet PBUH said:

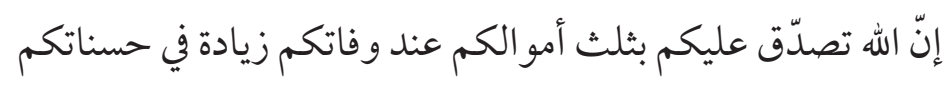

"Allah granted you a third of your wealth at the time of your demise to increase your good deeds..." 48

By and large, all evidences point to the fact that tawsiyah must not exceed a third, thus implying that the heirs share of the will must not be less than two thirds of the estate. Perhaps it may not be out of place at this juncture to inquire if it is permissible to have a will of more than one third of one's estate?

The ahädith quoted above are not only pointers to the fact that the testator (muwärrith) has the sole prerogative of disposing one third of his estate as a will and that he/she need not to seek permission from anyone in doing so. Thus, the heirs are entitled to the remaining two thirds. Therefore, if a testator makes a will of more than a third of his estate and his heirs consent to that being executed after the death of the muwärrith, it is so executed. However, if they refuse, the wasiyyah is made void and must be reduced to a third.

In another development, it is surmised that some ahādith suggest in terms of cash or monetization and that one thousand dirham is the permissible amount or minimum value of property out of which wașiyyah can be made. For instance, 'Alī b. Abī Țālib and Ibn 'Abbās were said to have refused to effect bequest on six hundred, seven hundred, and eight hundred dirham worth of property respectively. Indeed, ' $\bar{A}$ ' ishah, in another narration declares that one who left a property worth of eight hundred dirham has not left khayrān, whereas Qatādah opined that the word khayrān in ayāt al-wașiyyah should be interpreted to mean one thousand dirham. ${ }^{49}$

47 Al-Tirmidhī, Sunan al-Tirmidhī, vol. 3 (Madīnah: al-Maktabah al-Salafiyyah, n.d.), 291; Muḥammad bin Ismā'īl al-Amīr al-Yaman̄̄ al-San'an̄̄, Subl al-Salām: Sharḥ Bulūgh al-Marām Min Jāmi ‘ Adillat al-Aḥkām, no. hạāith 905.

48 See: M. A. Al-Shawkān̄̄, Nayl Awțār: Sharh Muntaqī al-Akhbar, part 6, no. hadīth 2515.

49 Sayyid Sābiq, Fiqh al-Sunnah, 380-381. 
An heir, normally, does not receive wașiyyah from his testator. If the testator, however, should grant a wasiyyah to an heir, then such is only executed when all the remaining heirs endorse it. ${ }^{50} \mathrm{Ibn}$ 'Abbās and others quoted the Prophet PBUH to having said:

$$
\text { لا تجوز وصيّة لوارث إلاً أن يشاء الورثة }
$$

"A legacy is not permitted for an heir save when the (other) heirs acceded to it" 51

Some of the Hanbalī fuqahā', the Shāfi'īs, al-Muzanī and the Zahirites, however, oppose the above tradition. ${ }^{52}$ The rationale behind the consent of other heirs according to al-Hidayah ${ }^{53}$ is not only that their right is attached to that 'will', for their share of the estate will definitely be reduced but to forestall hatred, enmity and strife between the heirs. Indeed, Islam cautions Muslim parents against undue as well as unequal gift distribution to their children. ${ }^{54}$

\section{FUNDAMENTALS OF WILL-MAKING IN ISLAM}

There is a divergence of opinion among the jurists on what constitutes the fundamentals of will-making (arkān al-wașiyyah). Jurists like Abū Hanīfah, Abū Yūsuf and Muhammad al-Shaybanī of the Hanafîs rule that only the proposal ( $\bar{l} j \bar{a} b)$ and acceptance $(q a b \bar{u} l)$ of a 'will' form a single principle of the contract of legacy ( 'aqd al-wașiyyah). The testator (muwārrith/mūsì) must enact a 'will' legally and the recipient (mūsālahu) must accept it. It should be noted that taking possession $(q a b d)$ is not a requirement with will-making as it is the rule with a gift (hibah) ${ }^{55}$ However, Zufâr of the Hanafìs considers only the proposal from the $m \bar{u} s \bar{l}$ as the required fundamental while his proof is that

50 M. A. Al-Shawkāni, Nayl Awtār: Sharh Muntaqū al-Akhbar, 142. See also Joseph Kenny (trans), The Risalah: Treatise on Maliki Law of 'Abdallah Ibn Abi Zayd alQayrawān̄ (922-996) (Minna: Islamic Education Trust, 1992), 150.

51 M. A. Al-Shawkāni, Nayl Awtār: Sharh Muntaqī al-Akhbar, 142, part 6, no. hadīth $2518 \& 2519$.

52 A. H. Marghanani, al-Hidāyah: Sharh al-Bidāyah al-Mubtadī, vol. 4 (Cairo: Matba'ah Musțafā al-Halabī, n.d.), 233.

53 A. A. al-Bukhārī, Șaḥịh al-Bukhārī, vol. 3 (Cairo: Maktabah al-Jumhuriyyah, n.d.), 195.

54 Ibn Rushd al-Qurtūbī, Bidāyat al-Mujtahid wa al-Nihāyat al-Muqtașid (Abadin: Dār al-Kitāb al-Islāmiyyah, 1983), 401.

55 Al-Dardir, Aqrāb al-Musalik li Madhhab al-Imām Mālik, $3^{\text {rd }}$ ed. (Cairo: Matba'ah Mușțafā al-Ḥalābī, 1954), 184. 
no acceptance is required from the heirs in succession to the estate of their muwārrith, but is automatically ceded to the heirs. Abū Hanifah and fellow fuqahä, prove their argument by referring to the verse in the Quran:

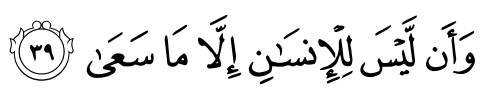

"And that man can have nothing but what he strives for ..."

(Surah al-Najm, 53: 39)

They further contend that by not ruling acceptance for wașiyyah as a principle, one may harm the recipient, for it may cause his death or cause some other disadvantages, like for some blind and crippled servants. Therefore, to obligate acceptance of bequest could in certain cases be harmful to the recipient and he must be given the chance of accepting or refusing the bequest. ${ }^{56}$

It should be noted that a Muslim has the right, according to al-Misrī, to rescind his bequest by taking back the article bequeathed. Thus, doing any of the following may be considered as taking back or annulling ones bequest:

- loss of ownership of the bequeathed article such as by sale, gift, or using it as collateral;

- when the substance of the article changes, such as wheat being grounded into flour, yarn woven into fabric, etc.; or

- if the beneficiary dies before the testator. ${ }^{57}$

A bequest in Shariah could be in writing or verbal. Whatever the form, it should be made in the presence of two witnesses (shāhidayn) who should be precluded from the legatees or his heirs. Mālikis, however, accept the validity of a written bequest if made in the familiar or known handwriting of the testator $(m \bar{u} s \bar{l})$ or under his own signature. So long as the intention of the testator is reasonably clear, the testament takes full effect. The testator is required to declare his intention and upon his death the bequeathed property is transferred to the legatee after acceptance. ${ }^{58}$

In sum, other jurists rule that the fundamentals of will-making include:

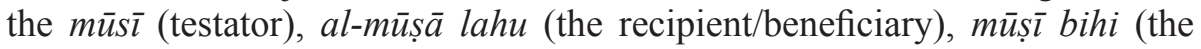
actual will), and the șighah (formula for enacting the contract of legacy). It

\footnotetext{
56 A. R. Jazā'irīi, Kitāb al-Fiqh 'alā Madhāhib al-Arba 'ah, 317.

57 Ahmad ibn Naqib al-Misri, Reliance of the Traveller: A Classic Manual of Islamic Sacred Law (Maryland, USA: Amana Corporation, 1997), 463.

58 Isa H. Chiroma, 'Conflict between Islamic Law and Common Law on the Testamentary Power (Wașiyyah): The Attitude of Nigerian Courts,' Islamic Studies, vol. 32/3 (1993): 340.
} 
is important to note that these fundamentals are not unguided and come with some conditions (shurūt). However, the conditions governing a valid bequest in Islam are outside the purview of this present paper.

\section{Philosophies Behind Will-Making (Hikām al-Wașiyyah) in Islam}

It is abundantly clear that wașiyyah is not devoid of basis in the Quran and Sunnah. Thus, its essence is not disconnected to the fact that it is one of the commandments of Allah (awāmir Allah) which makes it an imperative religious duty, for if one dies without leaving a will (intestate), he/she stands the risk of his/her property being distributed in accordance with English laws and which are intrinsically inimical to the Shariah. However, considering the injustice inflicted on the Muslims in South-West Nigeria in particular, by not giving them the legal system that suits their faith, ${ }^{59}$ there will be no harm if they deposit their will in the probate registry of the Ministry of Justice. This improvisation, to our mind, might be in line with the Islamic Jurists maxim which says:

$$
\begin{aligned}
& \text { ما لا يتم الواجب إلا به فهو واجب } 1 \text { مhatever is indispensable for an obligation is equally } \\
& \text { compulsory" }
\end{aligned}
$$

Thus, it becomes a religious duty for Muslims to deposit their will in the Probate Registry of the Ministry of Justice for obvious reasons.

It has been posited that it gives one peace of mind especially when the wishes and desires of the testator (muwārrith) are respected to the letter along with the avoidance of any unnecessary family disputes after one passes away According to Alade, the principles on which the legality of testamentary disposition might not be disconnected is that they defend and/or protect the rights of heirs' generally. ${ }^{60}$ Significantly, Islamic ordinances require that such a disposition should be for the benefit of non-heirs alone. A further reason why a bequest in favour of an heir is disallowed is that it would amount to giving preference to some heirs over others, thus defeating the spirit of the law which has fixed portions for each in the inheritance. However, if other heirs consent to a bequest to one of them or a bequest of more than one-third of the estate to

\footnotetext{
59 See T. M. Salisu, 'Sharī' ah: A Missing Law in the Schemes of Legal Options in South-Western Nigeria,' LASU Journal of Humanities, vol. 9 (2014): 45-65.

60 M. M. Alade, 'The Concept of Bequest (al-Wașiyyah) in Islam,' A Journal of Sharī'ah Law Students’'Association, vol. 1/4\&5 (1996): 63.
} 
another person, the above reasons no longer holds while the bequest is valid. ${ }^{61}$ Albeit, some scholars according to Ajetunmobi anchor the essence of wasiyah on seeking the pleasure of Allah (ridwwān Allāh), yet some other reasons best known to the testator might be implied. He writes inter alia:

\begin{abstract}
"Thus, some scholars opine that bequests are often made to seek the pleasure of Allah. In as much as some bequests are made to some distant relatives for the sake of Allah, we cannot rule out the above propositions of scholars in this regard. That notwithstanding, we contend that not all bequests are made for the sake of reward from Allah." 62
\end{abstract}

Therefore, wașiyah affords the testator the opportunity to help the less fortunate. In actual fact, leaving a gift in ones will to a charitable cause is not only helpful to the beneficiaries, but also the testator, for such gift(s) indubitably becomes ceaseless charity (sadaqah al-jāriyyah), for which its rewards span till after death. Ajijola corroborates thus: "If one maintains a sincere intention of pleasing Allah through helping the individual to whom he bequeathal will count as a șadaqah that will benefit him after death."

Writing a will, to our mind, is economical in the sense that it is relatively inexpensive, for dying intestate one's family will have to apply to the courts (probate registry) in order to administer ones estate which processes and procedures, which are not only lengthy but also too expensive as well. ${ }^{63}$

\title{
CONCLUSION
}

From the foregoing, it has been made lucid that death is a necessary requisite for will-making in Islam. Indeed, if the hadith of the Prophet that a conscious Muslim who has property to bequest should always within three nights endeavour to document it is properly digested and internalized, it is a reminder of the inevitable phenomena (al-mawt). It is also argued that bequest in Islam is antithetical to sympathy, favoritism and partiality, for there are clear Qur'ānic and ahādìth positions that lay credence to the concept. Indeed, there is the sharp contrast between will-making in Islam and all other conventional systems. This paper fairly dwells on the divergent views of jurists (fuqaha's')

${ }_{61}$ M. M. Alade, 'The Concept of Bequest (al-Wașiyyah) in Islam,' 63.

62 M. A. Ajetunmobi, 'Modern Development in Islamic Law of Testamentary Disposition,' 76.

63 An informant laments that he spent as much as 180,000:00 to process letter of administration for the estate of their late father. Alhaj Lamidi Salami (Member of the Ummah), in interview with author, 13 July 2009. 
using fiqh categorizations and benchmarks. This paper states further that no matter the level of a Muslim's magnanimity, he is not allowed to exceed onethird of his property and wealth, otherwise he may leave his family in abject pennilessness which the Prophet warned against. The fundamentals of bequest in Islam are well articulated, including the testator, the beneficiary, the bequest, and the formula for enacting the contract of legacy. It is submitted in this paper that the concept of will-making in Islam is a divine mandate, hence an ideal Muslim is expected to live in accordance with the teachings and tenets of Islam of which the act of bequest is an integral part of.

\section{REFERENCES}

'Alī, 'Abdullah Yūsuf, The Qur'ān: Translation and Commentary (England, IPCI: Islamic Vision, 1999).

A. A. al-Bukhārī, Saḥ̄ḥ al-Bukhārī, vol. 6 (Cairo: Maktabah al-Jumhūriyyah, n.d.).

A. A. al-Qurțubī, al-Jāmi ' li Aḥkām al-Qur’ān, vol. 2 (Cairo: al-Makṭabah al'Arabiyyah, 1967).

A. al-Tirmidhī, Sunan al-Tirmidhī, vol. 3 (al-Madīnah: al-Maktabah alSalafiyyah, n.d.).

A. B. al-Sijistānī, Sunan $A b \bar{\imath} D \bar{a} w \bar{u} d$, vol. 2 (Cairo: Maṭa'ah Mușțafā alHalābī, 1983).

A. H. Marghanani, al-Hidāyah: Sharh al-Bidāyah al-Mubtad̄̄', vol. 4 (Cairo: Maṭba'ah Musțafā al-Halābī, n.d.).

A. M. Ibn Hazm, al-Muhallā, vol. 9 (Cairo: Dār al-Turāth, n.d.).

A. O. Omotosho, 'The Language Factor in the Interpretation of Islamic Law: The Word Amr in Focus,' Nasarawa State University Law Journal, vol. 1/1 (2004): 131-142.

A. R. al-Jazā'irī, Kitāb al-Fiqh 'alā al-Madhāhib al-Arba'ah, vol. 3 (Cairo: al-Maktabah al-Tijāriyyah al-Kubrā, n.d.).

Abdul Malik Bappa Mahmud, Supremacy of Islamic Law (Zaria: Hudahuda Publishing Company, n.d.).

Abdulmumini A. Oba, 'Can A Person Subject to Islamic Law Make a Will in Nigeria?: Ajibaiye v. Ajibaiye and Mr. Dadem's Will Goose Chase,' CALS: Review of Nigerian Law and Practice, 2/2 (2008), works.bepress. com/abdulmumini_oba/15, accessed on 11 June 2010.

Abdur Raḥmān I. Doi, Sharī'ah: The Islamic Law (London: Ta-Ha Publishers Ltd., 1984). 
Abū al-A'lā Mawdūd̄̄, The Meaning of the Qur'ān: Arabic Text with Translation and Commentary, vol. I (London: n.p., n.d.).

Abū Bakr Jābir al-Jazā'irī, Minhāj al-Muslim, $8^{\text {th }}$ ed. (Lebanon: Dār al-Fikr, 1976).

Abūbakar Sadiq Ogwuche, Compendium of Islamic Law (Lagos: Maiyati Chambers, 2006).

Ahmad Ibn Naqib al-Misri, Reliance of the Traveller: A Classic Manual of Islamic Sacred Law (Maryland, USA: Amana Corporation, 1997).

al-Dardīr, Aqrab al-Muṣālik li Madhhab al-Imām Mālik, $3^{\text {rd }}$ ed. (Cairo: Mațba'ah Mustafā al-Halābī, 1954).

al-Hafĩz Ibn Hajar al-Asqalānī, Bulūgh al-Marām: Attainment of the Objective According to Evidence of the Ordinances (Riyāḍ: Dār al-Salām Publications, 1996).

al-Majmū', Sharh al-Muhadhdhab, vol. 15 (Beirūt: Dār al-Fikr, n.d.).

Hāfiz Zakī al-Dīn 'Abd al-'Aẓ̄m al-Munzirī, Mukhtașar Șaḥ̄h Muslim, $3^{\text {rd }}$ ed. (Damascus: al-Maktab al-Islāmī, 1977).

Edward William Lane, Arabic-English Lexicon, Book 1-Part 8 (London: William and Norgate, 1893).

Fazlur-Raḥmān, 'Economic Principles of Islam,' in Studies in Islamic Economics, ed. Khurshid Ahmad (United Kingdom: The Islamic Foundation, 1980).

I. D. Ibn Kathīr, Tafsīr al-Qur'ān al-'Azìm, vol. 1 (Beirūt: Dār al-Andalus, 1966).

Ibn Manzūr al-Ifriqī, Lisān al-'Arab, vol. 6 (Cairo: Dār al-Ma'ārif, n.d.).

Imām Ibn Hajar al-'Asqalānī, Fatḥ al-Bārī: Sharh Ṣahīh al-Bukhārī, vol. 5 (n.p.: Dār al-Bayān al-'Arabī, n.d.).

Isa H. Chiroma, 'Conflict Between Islamic Law and Common Law on the Testamentary Powers (Wașiyyah): The Attitude of Nigerian Courts,' Islamic Studies, 32/3 (1993).

J. Milton Cowan, A Dictionary of Modern Written Arabic (London: Macdonald \& Evans Ltd., 1974).

Joseph Kenny (trans.), The Risāla: Treatise on Māliki Law of 'Abdallah Ibn Abī-Zayd al-Qayrawān̄i (922-996) (Minna: Islamic Education Trust, 1992). 
L. M. Adetona, 'Aspects of Islamic Law: Acquisition and Distribution of Wealth and Penal Code,' in Diploma in Arabic and Islamic Studies Students' Hand Book, ed. M. A. Muhibbu-Dīn \& A. I. Lawal (Lagos: Arabic and Islamic Studies Units of the Lagos State University, 1998).

M. A. al-Shawkānī, Nayl al-Awțār: Sharḥ Muntaqī al-Akhbar min Hadīth Sayyid al-Akhyār, vol. 6 (Cairo: Maṭba'ah Muṣțafā al-Halābī, n.d.).

M. al-Qurțūbī, Bidāyat al-Mujtahid wa Nihāyat al-Muqtaṣid, vol. 2 (Cairo: Maktabah al-Kulliyat al-Azhariyyah, 1966).

M. D. Ibn Athar, Jāmi' al- 'Ușūl fì Ahāàith al-Rasūl, vol. 11 (Damascus: Makțabah al-Hilwān̄̄, 1970).

M. J. al-Mughniyyah, al-Fiqh 'alā Madhāhib al-Khamsah, vol. 2 (Beirūt: Dār al-'Ilm li al-Malayin, 1979).

M. M. Alade, 'The Concept of Bequest (al-Wașiyyah) in Islam,' Journal of Shariah Law Students's Association, vol. 1 (1996).

M. O. Raheemson, 'Ethics of Trade Transactions in Islam and its Relevance in Contemporary Times,' (Ph.D Thesis, Department of Arabic and Islamic Studies, University of Ibadan, 2001).

M.A. Ambali, The Practice of Muslim Family Law in Nigeria (Zaria: Tamaza Publishing Company Limited, 1998).

Moulana Moosa Ibn Ahmed Olgar, The Book of Wealth (South Africa: Tarbiyat Publications, 2001).

Muḥammad 'Alī, A Manual of Hadìth (Lahore: The Aḥmadiyyah Anjuman Ishaat Islam, n.d.).

Muḥammad b. 'Alī b. Muḥammad al-Shawkānī, Nayl al-Awṭ̂̄r, vol. vi (Beirūt: Dār al-Fikr, n.d.).

Muhammad b. Jarīr al-Tabarī, Tafsīr al-Ṭabarī: Jāmi ' al-Bayān 'an Ta'wīl alQur'ān, vol. 3, ed. Shākir (Misra: Dār al-Ma'arif, n.d.).

Muḥammad bin Ismā'îl al-Amīr al-Yaman̄̄ al-San'anī, Sublu al-Salām: Sharh Bulūgh al-Marām min Jāmi ' Adillah al-Aḥkām, vol. 3 (Cairo: Dār alFajr li al-Turāth, 2005).

Muḥammad Fuwād 'Abd al-Bāqī, al-Mu 'jam al-Mufahris li Alfāz al-Qur'ān al-Karìm (Beirūt: Dār al-Fikr, 1987).

Muhammad Mahdi al-Sharif (trans.), Sunan An-Nasā' $\bar{\imath}$ : The Fifth Correct Tradition of the Prophetic Sunna, vol. 3 (Beirūt: Dār al-Kutub al'Ilmiyyah, 2008). 
Muhammad Rahimuddīn (trans.), Muwātțā' Imām Mālik: Translated with Exhausted Notes (Beirūt: Muwasasah al-Ṭiba'ah wa al-Taswīr alKutaruniyyah, n.d.).

Muḥammad Taq̄i al-Dīn al-Hilālē \& Muḥammad Muḥsin Khān, The Noble Qur'ān: English Translation of the Meanings and Commentary (Madīna: King Fahd Complex, 1404A.H.).

Musa 'Ali Ajetunmobi, 'Modern Development in Islamic Law of Testamentary Disposition,' in Hamdard Islamicus: A Quarterly Journal of Bayt alHikmah, vol. xv (Pakistan: Hamdard Foundation, 1992).

Sayyid Sābiq, Fiqh Sunnah, vol. 3 (Lebanon: Dār al-Fikr, 1983).

T. M. Salisu, 'Shari' ${ }^{-}$ah: A Missing Law in the Schemes of Legal Options in South Western Nigeria,' LASU Journal of Humanities, vol. 9 (2014): 45-65.

T. M. Salisu, 'The Infiltration of Custom (al-'Ādah) into Islamic Marriages (An-Nikkāh) in Yorubaland,' Journal of Religion and Culture, vol. 1/2 (2000). 